\title{
KARAKTERISTIK SIFAT FISIKA TANAH ULTISOL AKIBAT PEMBERIAN BIOCHAR BERBAHAN BAKU SISA TANAMAN KELAPA SAWIT
}

\author{
Abdul Rauf ${ }^{* *}$, Supriadi ${ }^{1}$, Fitra Syawal Harahap ${ }^{2 *}$, Makruf Wicaksono ${ }^{3}$ \\ ${ }^{1)}$ Program Studi Agroteknologi Fakultas Pertanian Universitas Sumatera Utara \\ ${ }^{2)}$ Program Studi Agroteknologi Fakultas Sains dan Teknologi Universitas Labuhan Batu. \\ 3)Politeknik Pembangunan Pertanian Medan (Polbantang) Sumtera Utara 20002 \\ *Corresponding author : a.raufismail@gmail.com, fitrasyawalharahap@gmail.com
}

\begin{abstract}
The physical characteristics of ultisols due to the provision of biochar made from palm oil plant residue aims to determine the effect of giving various biochar made from oil palm plant residues on the physical properties of Ultisols. The research design used completely randomized design, consisting of 5 treatments, namely $\mathrm{K}=$ without giving biochar, $\mathrm{BB}=$ oil palm stem biochar, $\mathrm{BP}=$ oil palm frond biochar, $\mathrm{BT}=$ oil palm empty bunches biochar and $\mathrm{BK}=$ combination of biochar ingredients. Each treatment was repeated 4 times, so that the number of experimental units became 20 units. The parameters observed included soil density, soil porosity, soil texture, soil permeability and available water. The results showed that giving biochar significantly decreased the bulk weight and significantly increased the soil porosity of Ultisols.
\end{abstract}

Key words : biochar, oil palm wastes, physical properties of soil and ultisol

(c) 2020 Rauf, Supriadi, Harahap, Wicaksono

\section{PENDAHULUAN}

Perkebunan kelapa sawit merupakan perkebunan terluas di Indonesia. Pada saat ini perkebunan kelapa sawit telah memasuki generasi kedua, dimana beberapa perkebunan telah dilakukannya replanting dari kegiatan tersebut dihasilkan sisa-sisa tanaman seperti akar, batang maupun pelepah. Sisasisa tanaman tersebut belum banyak dimanfaatkan, terutama pada perkebunan rakyat sisa-sisa tanaman tersebut dibiarkan saja sampai membusuk dengan sendirinya.

Penelitian tentang keragaman jenis bahan organik yang dapat dimanfaatkan sebagai bahan baku biochar sudah banyak. Diantaranya yaitu jerami padi (Maftu'ah dan Nursyamsi, 2015), cangkang kelapa sawit (Santi dan Goenadi, 2012), jerami jagung dan tandan kosong kelapa sawit (Maftu'ah dan Nursyamsi, 2015), serbuk gergaji (Komarayati et al., 2012), dan sekam padi (Maftu'ah dan Nursyamsi, 2015; Saputra et al., 2016).

Salah satu pemanfaatan sisa tanaman kelapa sawit adalah dengan mengolah sisa tanaman tersebut menjadi biochar. Pembuatan biochar dengan bahan baku dari tanaman kelapa sawit merupakan salah satu solusi dalam mempercepat pengolahan limbah padatan serta menjadi alternatif lain dalam pemanfaatan limbah tersebut. Salah satu cara untuk mengolah kembali limbah baik dari hasil pertanian ataupun sampah kota adalah dengan membuat limbah tersebut menjadi biochar. Pembuatan limbah pertanian menjadi biochar merupakan salah satu cara untuk 
memanfaatkan limbah - limbah tersebut menjadi berguna terkhusus untuk lahan pertanian terutama pada lahan yang memiliki banyak permasalahan seperti pada tanah ultisol. Biochar adalah zat arang kayu berpori, sering disebut arang atau agri-char. Pemanfaatan bahan organik berupa biochar juga diketahui dapat meningkatkan kesuburan kimiawi, fisik, dan biologis tanah. Biochar mampu memperbaiki tanah melalui kemampuannya meningkatkan $\mathrm{pH}$, mempertahankan unsur hara, dan memberikan lebih banyak unsur hara bagi tanaman (Maftu'ah dan Nursyamsi, 2015; Santi dan Goenadi, 2012), tidak mengganggu keseimbangan karbon-nitrogen, menahan air ( Santi dan Goenadi, 2012) penyediaan habitat yang baik bagi mikroba tanah meningkatkan aktivitas biota di dalam tanah dan mengurangi pencemaran (Maftu'ah dan Nursyamsi, 2015; Santi dan Goenadi, 2012).

Pengaplikasian biochar terhadap tanah-tanah marjinal seperti halnya pada tanah ultisol sangatlah diperlukan. Pemberian biochar dimaksudkan untuk memperbaiki sifat-sifat tanah tersebut. Hasil penelitian Santi dan Goenadi (2010) bahwa Biochar memiliki keunggulan dibandingkan kompos dan gambut dalam hal Bulk Density(BD), kerapatan partikel (PD), Total ruang pori dan kapasitas air tersedia yang tergolong tinggi.

Tanah Ultisol disamping memiliki sebaran yang sangat luas $(25 \%$ dari total daratan Indonesia) juga memiliki penampang tanah yang dalam dan kapasitas tukar kation yang tergolong sedang hingga tinggi menjadikan tanah ini mempunyai peranan yang penting dalam pengembangan pertanian lahan kering di Indonesia (Prasetyo dan Suriadikarta 2006). Hampir semua jenis tanaman dapat tumbuh dan dikembangkan pada tanah ini, kecuali terkendala oleh iklim dan relief. Kesuburan alami tanah Ultisol umumnya terdapat pada horizon A yang tipis dengan kandungan bahan organik yang rendah

Karakteristik sifat fisika tanah perlu dilakukan sehingga dapat berguna untuk mengetahui kemampuan tanah secara fisik dan berperan dalam pelestarian tanah dan air (komponen abiotik). Dimana sifat fisika tanah mempunyai kemampuan kapasitas untuk melakukan drainase dan menyimpan air, plastisitas, kemudahan untuk ditembus akar, aerasi dan kemampuan menahan retensi unsur-unsur hara tanaman (Foth, 1984). Pemberian biochar mampu meningkatkan kapasitas tanah dalam menahan air serta memperbaiki agregasi tanah, sehingga akar mudah menembus tanah dan jangkauan akar mencari air serta unsur hara menjadi lebih jauh (Glaser et al., 2002).

sehingga mengetahui karakteristik sifat fisika tanah ultisol akibat pemberian biochar berbahan baku sisa Tanaman Kelapa Sawit khususnya perkebunan kelapa sawit dalam memperbaiki sifat fisik tanah pada tanah Ultisol. Tujuan penelitian ini adalah untuk mengetahui pengaruh pemberian berbagai bahan baku biochar dari sisa tanaman kelapa sawit dalam memperbaiki sifat fisik tanah Ultisol.

\section{BAHAN DAN METODA}

Penelitian ini dilaksanakan pada November 2018 sampai dengan bulan Juli 2019 di Rumah Kaca, Laboratorium Riset dan Teknologi, Laboratorium Fisika Tanah Fakultas Pertanian Universitas Sumatera Utara dan Laboratorium Pusat Penelitian Kelapa Sawit (PPKS).

Metode Penelitian menggunakan metode eksperimen di Rumah Kaca dan analisa tanah dilakukan di Laboratorium Riset dan Teknologi, Laboratorium Fisika Tanah Fakultas Pertanian Universitas 
Sumatera Utara dan Laboratorium Pusat Penelitian Kelapa Sawit PPKS. Penelitian menggunakan Rancang Acak Lengkap dengan 5 perlakuan dan 4 ulangan:

$\mathrm{K}$ : Kontrol (Tanpa Perlakuan), BB : biochar batang kelapa sawit, BP : biochar pelepah kelapa sawit, BT : biochar tandan kosong kelapa sawit, BK : biochar batang kelapa sawit + pelepah kelapa sawit + tandan kosong kelapa sawit.

Pemberian dosis sendiri berdasarkan jumlah bahan organik yang terdapat di dalam tanah sebanyak 3\%. Jumlah perlakuan adalah 5 Unit dengan 4 Ulangan, maka jumlah unit penelitian adalah 20 unit penelitian. Model linier Penelitian ini adalah Rancangan Acak Lengkap (RAL) non faktorial adalah sebagai berikut :Yij = $\mu+\tau \mathrm{i}+\varepsilon \mathrm{ij}$. Dimana : Yij $=$ Nilai pengamatan pada perlakuan ke-i dan ulangan ke- $\mathrm{j}, \mu=$ Nilai tengah umum, $\tau \mathrm{i}=$ Pengaruh perlakuan ke-i, $\varepsilon \mathrm{ij}=$ Pengaruh galat (error) percobaan perlakuan ke-i dan ulangan ke-j

Selanjutnya data dianalisis dengan Analisis of Variance (ANOVA) untuk setiap parameter yang diukur dan diuji lanjutan bagi perlakuan yang nyata dengan menggunakan Uji Jarak Berganda Duncan (Duncan's Multiple Range Test) dengan taraf 5\%.

Parameter Yang Diamati meliputi:

a. Pengukuran kerapatan isi tanah (bulk density) dilakukan pada sampel yang diambil pada tanah yang diinkubasi selama 8 minggu. Contoh tanah utuh diambil menggunakan ring sample. Menganalisis Kerapatan isi tanah dihitung dengan menggunakan Persamaan :

b. Porositas (\%) diperoleh bobot isi tanah sudah ditentukan. Data yang harus diketahui lainnya adalah bobot jenis partikel yaitu 2,65 $\mathrm{g} / \mathrm{cm}^{3}$. Menganalisis porositas tanah Porositas dihitung dengan menggunakan Persamaan :\

c. Pengukuran permeabilitas dengan metode Constant Head Test.

$$
\rho_{\mathrm{s}}=\frac{\mathrm{Ms}}{\mathrm{Vt}}
$$

d. Menganalisa air tersedia Air tersedia dapat dihitung dengan menghitung selisih antara $\mathrm{Uji} \mathrm{pF}$ 2,54 (kapasitas lapang) dan $\mathrm{pF}$ 4,2 (titik layu permanen) menggunakan metode pressure plate di Laboratorium Pusat Penelitian Kelapa Sawit (PPKS).

$$
F=\left(1-\underline{\rho}_{\underline{s}}\right) \times 100 \%
$$

\section{HASIL DAN PEMBAHASAN \\ 1. Hasil \\ Kerapatan Isi Tanah}

Dari data pengukuran kerapatan isi tanah (Tabel 1), dan dari hasil sidik ragam kerapatan isi tanah diperoleh bahwa pemberian biochar memberikan pengaruh yang nyata terhadap kerapatan isi tanah. nilai kerapatan isi tanah dapat dilihat pada Tabel 1.

Dari Tabel 1, dapat diketahui bahwa pemberian biochar dari beberapa jenis bahan baku mampu meningkatkan secara nyata kerapatan isi tanah. Kerapatan isi tanah terendah terjadi pada perlakuan BP (Biochar Pelepah Kelapa Sawit) dengan kerapatan isi tanah sebesar $1,02 \mathrm{~g} / \mathrm{cm}^{3}$. Sedangkan untuk kerapatan isi tanah tertinggi terdapat pada perlakuan $\mathrm{K}$ (Kontrol) sebesar $1,19 \mathrm{~g} / \mathrm{cm}^{3}$. Namun untuk perlakuan BB (Biochar Batang Kelapa Sawit) belum mampu meningkatkan kerapatan isi tanah secara nyata. 
Tabel 1. Nilai Kerapatan isi Tanah akibat pemberian biochar dari beberapa jenis bahan baku

\begin{tabular}{lc}
\hline \multicolumn{1}{c}{ Perlakuan } & Kerapatan Isi Tanah $\left(\mathrm{g} / \mathrm{cm}^{3}\right)$ \\
\hline K (Kontrol) & $1,19 \mathrm{c}$ \\
BB (Biochar Batang) & $1,07 \mathrm{~b}$ \\
BP (Biochar Pelepah) & $1,02 \mathrm{a}$ \\
BT (Biochar TKKS) & $1,05 \mathrm{a}$ \\
BK (Kombinasi Biochar) & $1,05 \mathrm{a}$ \\
\hline
\end{tabular}

Keterangan : Angka yang diikuti oleh huruf sama berarti tidak berbeda nyata (5\%) menurut uji DMRT

\section{Porositas}

Dari data pengukuran porositas tanah (Tabel 2), dari hasil sidik ragam porositas tanah diperoleh bahwa pemberian biochar memberikan pengaruh yang nyata terhadap porositas tanah. Nilai porositas tanah dapat dilihat pada tabel di bawah ini.

Dari Tabel 2 di atas dapat diketahui porositas terendah terjadi pada perlakuan $\mathrm{K}$ (Kontrol) sebesar 54,75\%. Sedangkan untuk porositas tanah tertinggi terdapat pada perlakuan BP (Biochar Pelepah Kelapa Sawit) sebesar 61,5\%. Pemberian biochar dari beberapa jenis bahan baku mampu meningkatkan secara nyata porositas tanah pada perlakuan BP (Biochar pelepah kelpa sawit), BT (biochartandan kosong kelapa sawit) dan BK (kombinasi bahan baku biochar). Namun untuk perlakuan BB (Biochar
Batang Kelapa Sawit) belum mampu meningkatkan porositas tanah secara nyata.

\section{Permeabilitas Tanah}

Pemberian biochar dari beberapa jenis bahan baku tidak berpengaruh nyata dalam memperbaiki permeabilitas tanah Ultisol (Tabel 3). Hal ini berdasarkan data pengukuran permeabilitas tanah dan dari hasil sidik ragam permeabilitas tanah. Berdasarkan berikut ini, diketahui bahwa pemberian antara pemberian biochar dari beberapa jenis bahan baku dengan tanpa pemberian biochar tidak memiliki pengaruh yang berbeda terhadap permeabilitas tanah. Nilai rataan permeabilitas tanah tertinggi terdapat pada perlakuan K (Kontrol) yaitu $24,92 \mathrm{~cm} / \mathrm{jam}$. Nilai rataan permeabilitas terendah terdapat pada BB (biochar batang) yaitu sebesar $17,90 \mathrm{~cm} / \mathrm{jam}$.

Tabel 2. Nilai Porositas Tanah akibat pemberian biochar dari beberapa jenis bahan baku

\begin{tabular}{lc}
\hline \multicolumn{1}{c}{ Perlakuan } & Porositas (\%) \\
\hline K (Kontrol) & $54,75 \mathrm{c}$ \\
BB (Biochar Batang) & $59,50 \mathrm{~b}$ \\
BP (Biochar Pelepah) & $61,50 \mathrm{a}$ \\
BT (Biochar TKKS) & $60,75 \mathrm{a}$ \\
BK (Kombinasi Biochar) & $60,25 \mathrm{a}$ \\
\hline
\end{tabular}

Keterangan : Angka yang diikuti oleh huruf sama berarti tidak berbeda nyata (5\%) menurut uji DMRT 
Tabel 3. Nilai permeabilitas tanah Ultisol akibat pemberian biochar dari beberapa jenis bahan baku.

\begin{tabular}{lcc}
\hline \multicolumn{1}{c}{ Perlakuan } & Permeabilitas Tanah $(\mathrm{cm} / \mathrm{jam})$ & Kriteria* \\
\hline K (Kontrol) & 24,92 & Cepat \\
BB (Biochar Batang) & 17,90 & Cepat \\
BP (Biochar Pelepah) & 19,43 & Cepat \\
BT (Biochar TKKS) & 24,50 & Cepat \\
BK (Kombinasi Biochar) & 23,25 & Cepat \\
\hline
\end{tabular}

*berdasarkan klasifikasi menurut Uhland dan O'Neil (dalam Arsyad, S. 1989)

\section{Air Tersedia}

Pemberian biochar dari beberapa jenis bahan baku belum memperbaiki ketersediaan air tanah (Tabel 4). Hal ini berdasarkan data pengukuran air tersedia. Nilai air tersedia dapat dilihat pada tabel di bawah ini.

Dari Tabel di atas, diketahui bahwa pemberian pemberian biochar dari beberapa jenis bahan baku tidak mempengaruhi ketersediaan air tanah. Nilai rataan air tersedia tertinggi terdapat pada perlakuan BT (Biochar TKKS) yaitu sebesar 4,99\%. Nilai air tersedia tertinggi terdapat pada perlakuan BP (Biochar Pelepah) yaitu sebesar $4,14 \%$.

Tabel 4. Nilai air tersedia tanah Ultisol akibat pemberian biochar dari beberapa jenis bahan baku.

\begin{tabular}{cc}
\hline Perlakuan & Air Tersedia (\%) \\
\hline K (Kontrol) & 4,85 \\
BB (Biochar Batang) & 4,75 \\
BP (Biochar Pelepah) & 4,14 \\
BT (Biochar TKKS) & 4,99 \\
BK (Kombinasi Biochar) & 4,81 \\
\hline
\end{tabular}

\section{Pembahasan}

Pemberian biochar dari bahan baku yang berbeda mampu menurunkan kerapatan isi tanah ultisol secara nyata. Biochar yang berasal dari bahan baku pelepah kelapa sawit mampu menurunkan kerapatan isi tanah paling tinggi yaitu mencapai $1,02 \mathrm{~g} / \mathrm{cm}^{3}$, kemudian diikuti oleh biochar dari tandan kosong kelapa sawit dan kombinasi biochar sebesar 1,05 $\mathrm{g} / \mathrm{cm}^{3}$, dan biochar dari batang kelapa sawit sebesar $1,07 \mathrm{~g} / \mathrm{cm}^{3}$. Hal ini sesuai dengan penelitian yang dilakukan oleh Verheijen et al. (2010) yang menyatakan bahwa pemberian biochar dapat menurunkan kerapatan isi tanah mineral karena penambahan biochar kedalam tanah mampu meningkatkan luas permukaan tanah sehingga meningkatkan ruang pori di dalam tanah. Menurut Masulili et al. (2010) pemberian biochar dapat menurunkan berat isi tanah akibat biocharyang memiliki sifat berporus sehingga meningkatkan ruang pori di dalam tanah. Ketika diberikan pada tanah menyebabkan pengaruh yang signifikan terhadap penurunan berat isi dan peningkatan volume pori tanah.

Dari hasil analisis didapatkan bahwa penambahan biochar ke dalam tanah memberikan pengaruh yang nyata terhadap porositas tanah. Peningkatan porositas 
sejalan dengan menurunnya kerapatan isi tanah, sehingga banyaknya suatu massa tanah dalam suatu volume tanah mampu menentukan banyak ruang pori di dalam tanah tersebut. Foth (1984) menyatakan porositas merupakan perbandingan antara kerapatan massa tanah dengan kerapatan partikel tanah, maka dari itu bisa dikatakan bahwa dalam suatu volume tanah terdiri dari massa tanah dan ruang pori tanah. Dengan demikian, tanah yang kerapatan massa rendah maka tanah tersebut memiliki ruang pori banyak, begitu pun sebaliknya. Jadi keberadaan dari ruang pori didalam tanah sangat menentukan besar kecilnya kerapatan massa suatu tanah (Sopher and Baird, 1982).

Porositas tertinggi terjadi pada perlakuan biochar pelepah kelapa sawit $61,50 \%$ kemudian diikuti oleh biochar dari tandan kosong kelapa sawit sebesar $60,75 \%$ kombinasi berbagai bahan baku biochar sebesar $60,25 \%$ dan perlakuan biochar batang sawit sebesar 59,75\%. Sedangkan untuk porositas terendah terdapat perlakuan tanpa pemberian biochar sebesar 54,75\%. Hal ini sesuai dengan penelitian Glasser et al. (2002) bahwa pengaruh yang disebabkan oleh biochar tidaklah sama semua, melainkan berbeda-beda berdasarkan dari masingmasing biochar tersebut. Pemberian biochar juga mampu memberikan habitat baru bagi mikroba tanah sehingga mampu mempengaruhi terbentuknya pori-pori tanah yang mengakibatkan meningkatnya porositas tanah (Zhaeittun, 2016).

Pemberian biochar dari berbagai bahan baku tidak memiliki pengaruh terhadap permeabilitas tanah, tetapi secara umum mampu meningkatkan permeabilitas tanah. Hal ini sesuai dengan penelitian yang dilakukan oleh Nurida dan Rachman (2012) menjelaskan bahwa aplikasi biochar dapat menurunkan permeabilitas akibat air tidak cepat hilang dari daerah perakaran sehingga retensi air juga meningkat. Permeabilitas tanah paling tertinggi terjadi diperlakuan kontrol yaitu sebesar 24,92 $\mathrm{cm} / \mathrm{jam}$, sedangkan permeabilitas tanah terendah terjadi pada perlakuan biochar batang sebesar $17,90 \mathrm{~cm} / \mathrm{jam}$ dan semua perlakuan tergolong ke dalam kelas cepat. Hal ini berdasarkan pengklasifikasian permeabilitas tanah menurut Uhland dan O'Neil (1951) yang menyatakan permeabilitas tanah 12,5-25,00 cm/jam termasuk kedalam kelas cepat (Arsyad, 1989). Permeabilitas tanah dipengaruhi oleh sebaran pori tanah Jika sebaran ukuran pori suatu tanah didominasi oleh pori berukuran besar (pori makro) maka tanah ini memiliki kemampuan melewatkan air dan udara yang besar (Arifin, 2011).

Berdasarkan hasil analisa dapat dilihat bahwa air tersedia tertinggi pada perlakuan BT (Biochar Tandan Kosong Kelapa Sawit) sebesar 4,99\% sedangkan untuk nilai air tersedia terendah terjadi pada perlakuan BP (Biochar Pelepah Kelapa Sawit) sebesar 4,14 \%. Salah satu faktor yang mempengaruhi ketersediaan air di dalam tanah adalah tekstur tanah. Tekstur tanah sangat mempengaruhi kemampuan tanah dalam meretensi air (Aslam et al., 2014). Tanah ultisol galang memiliki tekstur lempung berpasir yang dimana tanah tersebut memiliki dominan pasir sehingga kemampuan tanah untuk menahan air rendah. Menurut Sutono dan Nurida (2012) Biochar tempurung kelapa sawit memiliki kemampuan menyerap air yang tinggi hingga $>50 \%$ volume, namun tidak diimbangi dengan kemampuan menyimpannya karena cepat sekali kehilangan air. Keadaan seperti inilah yang menyebabkan pemberian biochar tidak memiliki pengaruh yang signifikan terhadap ketersediaan tanah ultisol. Selain itu juga ketersediaan air didalam tanah juga 
dipengaruhi oleh sebaran ukuran pori didalam tanah. Tanah bertekstur kasar kaya pori-pori makro yang mengalami drainase bebas sehingga kemampuan menyimpan lengas yang rendah. Tanah bertekstur halus memiliki lebih banyak pori mikro yang mampu menahan air untuk melawan drainase bebas (USDA, 2008).

\section{KESIMPULAN}

Pemberian biochar berbahan baku sisa tanaman kelapa sawit nyata memperbaiki kerapatan isi tanah dan porositas tanah, dan tidak nyata memperbaiki sifat fisik tanah lainnya.

\section{DAFTAR PUSTAKA}

Arifin, Z. 2011. Analisis Nilai Indeks Kualitas Tanah Entisol pada Penggunaan Lahan yang Berbeda. J. Agroteksos 21(1) : $47-54$.

Arsyad, S., 1989. Konservasi Tanah dan Air. IPB Press, Bogor.

Aslam, Z., Khalid, M. and Aon, M. 2014. Impact of biochar on soil physical properties. Scholarly Journal of Agricultural Science 4(5), 280-284.

Foth, H. D., 1984. Fundamentals Of Soil Science Seventh Edition. John Wiley \& Sons,New York.

Glaser B, Lehmann J, Zech W. 2002. Ameliorating physical and chemical properties of highly weathered soils in the tropics with charchoal. Biol. Fertil. Soils. 35: 219- 230.

Komarayati, S., Gusmailina., dan G. Pari. 2012. Arang dan Cuka Kayu: Produk Hasil Hutan Bukan Kayu untuk Meningkatkan
Pertumbuhan Tanaman dan Serapan Hara. Penelitian Hasil Hutan 31 (1): 49-62.

Masulili, A., Utomo, W.H. and Syechfani, M.S. 2010. Rice husk biochar for rice based cropping system in acid soil 1 . the characteristics of rice husk biochar and its influence on the properties of acid sulfate soils and rice growth in West Kalimantan, Indonesia. Journal of Agriculture Science 2 (1), 39-47.

Maftu'ah, E. dan D. Nursyamsi. 2015. Potensi berbagai Bahan Organik Rawa sebagai Sumber Biochar. Seminar Nasional Masyarakat Biodiv Indonesia. 1(4) : 776-781.

Nurida, N.L., A. Rachman, dan Sutono. 2012. Potensi Pembenah Tanah Biochar dalam pemulihan sifat tanah terdegradasi dan Peningkatan Hasil jagung pada Typic Kanhapludults Lampung. Prosiding Seminar Nasional tentang Pengelolaan Limbah Biomasa sebagai Sumber Energi Terbarukan, Pertanian Berkelanjutan, dan Mitigasi Pemanasan Global (Prospek Konversi Biomassa ke Biochar di Indonesia). Unitri. Malang.

Nurida, N.L. dan Rachman, A. 2012. Alternatif Pemulihan Lahan Kering Masam Terdegradasi dengan Formula Pembenah Tanah Biochar di Typic Kanhapludults Lampung. Diterbitkan pada Prosiding Seminar Nasional Teknologi 
Pemupukan dan Pemulihan Lahan Terdegradasi. Dalam Wigena (Eds.), Badan Penelitian dan Pengembangan Pertanian, Kementerian Pertanian, Bogor, 29-30 Juni 2012. p. 639-648.

Prasetyo, B. H. dan D.A. Suriadikarta. 2006. Karakteristik, Potensi, Dan Teknologi Pengelolaan Tanah Ultisol Untuk Pengembangan Pertanian Lahan Kering Di Indonesia Jurnal Litbang Pertanian, 25(2).

Santi, L. P. dan D. H. Goenadi. 2010. Pemanfaatan bio-char sebagai pembawa mikroba untuk pemantap agregat tanah Ultisol dari Taman Bogo-Lampung. Menara Perkebunan 2010, 78(2), 52-60.

Santi, L. P dan D. H. Goenadi. 2012. Pemanfataan Biochar asal Cangkang Kelapa Sawit sebagai Bahan Pembawa Mikroba Pemantap Agregat. Buana Sains 12 (1): 7-14.

Saputra, A. R. T., L. Rahmawati., D. Budianta., dan S. J. Priatna. 2016. Serapan Nitrogen pada Pertumbuhan Padi (Oriza Sativa L.) dengan Pemberian Biochar di Lahan Rawa Lebak. Prosiding Seminar Nasional Lahan Suboptimal. Palembang.
Sopher, C. D and J. V. Baird. 1982. Soils and Soil Management. Reston Publishing Company, Inc, Virginia.

Sutono, S., dan Nurida, N.L. 2012. Kemampuan biochar memegang air pada tanah bertekstur pasir. Buana Sains 12 (1), 45-52

Uhland R.E., and O'neal A.M. 1951. Soil Permeability Determinations For Use In Soil and Water Conservation. SCS-TP-101, 36 pp., Illus, New York.

USDA. 2008. Soil Quality Indicators. USDA Natural Resources Conservation Services.

Verheijen, F., S. Jeffery, A.C. Bastos, M. van der Velde, and I. Diafas. 2010. Biochar Application to Soils A Critical Scientific Reviewof Effects on Soil Properties, Processes and Functions. JRC Scientific and Technical Repots.

Zhaeittun, P. P. 2016 Pengaruh Biochar Terhadap Sifat Fisik Tanah dan Agregat Halus Contoh Tanah Typic Kanhapludult Kebun Percobaan Taman Bogo, Lampung Timur. Skripsi, Fakultas Pertanian, Institut Pertanian Bogor, Bogor 